\title{
Mental health and corporate social responsibility for industrial psychology
}

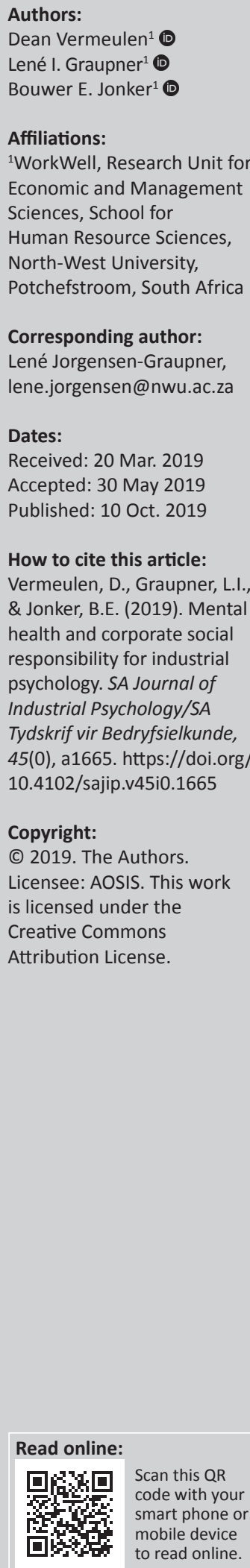

Orientation: Organisations must do whatever it takes to ensure sustainability and longevity, and extend benefits into the communities where they operate.

Research purpose: The general aim of this study was to explore the contribution that the profession of industrial psychology can make towards improving mental health by means of a CSR programme.

Motivation for the study: This study was motivated by the notion that, in South Africa, organisations are encouraged to be socially responsible and Industrial-organisational Psychology (IOP) can be of service to this goal for the organisation.

Research approach/design and method: A qualitative research design with a combination of purposive and convenience sampling was utilised. Participants consisted of the project team who participated in a training institution's CSR initiative in the North West province. Data gathering took place in the form of semi-structured in-depth interviews, which were transcribed verbatim and analysed using thematic analysis.

Main findings: The results showed that typical IOP topics that could be formulated into a CSR programme included life skills and topics related to personal growth and self-worth. The results also showed that universities are able to play a vital part in community engagement, and an inter-relationship of benefits can be established.

Practical/managerial implications: The research indicates that industrial and organisational psychologists could also contribute to organisations when they operate in the CSR scope.

Contribution/value-add: On an individual level, this study contributed to clarify the understanding whether IOP has a place in social investment and contributions.

Keywords: Corporate social responsibility; Mental health; Industrial psychology; Career counselling; Workplace counselling; Young adults.

\section{Introduction}

In the global organisational arena, the concept of Corporate Social Responsibility (CSR) has been, and is, continually growing in terms of its importance and operationalisation. The concept of CSR is developing not only in terms of awareness but also in terms of interest in the concept (Serenko \& Bontis, 2009). This growth has been argued by Okpara and Idowu (2013) as a result of the impact of unethical business practices and growing social concerns, as well as because of the growing role of corporations as global governance role-players that are especially discussed within political CSR research (Gilbert, Rasche, Schormair, \& Singer, 2019). Okpara and Idowu (2013) furthermore indicate that in the contemporary business world, the exposure of unethical business leads to a decline in public confidence, which could be an enormous threat to the sustainability of the modern organisation. The ease of publicity that organisations enjoy in the modern age has the equal power to expose organisations that operate irresponsibly and unethically. This ease of publicity has highlighted the importance of impression management, creating the need for organisations to manage their operations concerning social responsibility more carefully (Okpara \& Idowu, 2013).

Note: This article is partially based on the author's mini-dissertation for the degree Magister Commercii in Industrial Psychology at the Potchefstroom Campus of the North-West University, South Africa, with supervisor Prof. L.I. Jorgensen and co-supervisors Mr B.E. Jonker and Ms H. Jonker, received November 2016, available here: https://dspace.nwu.ac.za/bitstream/handle/10394/25931/Vermeulen_D_ 2016. pdf?isAllowed $=\mathrm{y} \&$ sequence $=1$. 
Aguinis and Glavas (2012) argue that apart from its popularity, CSR as a concept is still somewhat fragmented and elusive to conceptualise in a single domain. Different industries and professions define CSR differently (Aguinis \& Glavas, 2012). In light of this multi-dimensionality of CSR, this research article will investigate the concept of CSR through the perspective of the profession of Industrial-Organisational Psychology (IOP). A literature review follows to conceptualise CSR from its global origins, moving towards the South African perspectives and applications, and finally integrating the concept into the dimensions and workings of the IOP profession. To further this conceptualisation, a case study was conducted to understand how the IOP can function in CSR roles. This is followed by a presentation of the methodology used in the study, reporting on the findings and drawing conclusions.

\section{Corporate social responsibility}

Corporate social responsibility is a concept that can be described as being multi-disciplinary and multi-level, which has undergone significant changes in the way it is understood and conceptualised. Moura-Leite and Padgett (2011) write that in the early 1950s, CSR was focused on doing good deeds for the society in which the organisation operated. These good deeds were mainly in the form of charitable contributions or presence in the immediate community. Moving into the modern and contemporary organisation, the concept of CSR has been adopted as a part of strategic business and success (Moura-Leite \& Padgett, 2011). Defining CSR further varies within the context of different organisations, disciplines and industries. Dahlsrud (2008) indicates that CSR is mainly a concept whereby organisations focus on social and environmental concerns in their business operations. Organisations that engage in CSR can argue either the business case or the moral case for CSR. The business case for CSR, as indicated by Carroll and Shabana (2010), is underpinned by the notion that the organisation will enjoy financial benefits from CSR. On the contrary, the ethical case appeals to the morality and humanistic responsibility the organisation should have to serve society and conduct its operations responsibly (Okpara \& Idowu, 2013).

The business case for CSR highlights that the organisation will make money from CSR, referring to the triple bottom-line returns. The triple bottom-line refers to social, environmental and economic prosperity (Okpara \& Idowu, 2013). In agreement with this notion, Rossouw and Van Vuuren (2010) state that organisations can garner many positive benefits from engaging in CSR if they understand what CSR means for the business when they do indeed engage and when they do not. Carroll and Shabana (2010) opine that the primary way in which organisations benefit financially from CSR is through competitive advantage by means of stakeholder relationships. Creating healthy stakeholder relationships and a stable reputation for the organisation is the theme that supports the business case for CSR.

The moral case for CSR supports the ideals of responsible business, business ethics and moral rights. Ackers (2015) indicates that organisations have a moral obligation and duty towards the various groups of society - the argument being that society has a strong involvement in how organisations operate by being customers, supporters and stakeholders in the organisation's sustainability. Furthermore, the literature indicates that the ways in which individual organisations deploy CSR can also differ. Aguinis and Glavas (2013) provide a conceptual framework by mentioning that CSR can be implemented as either embedded or peripheral in nature. This framework is groundbreaking in terms of idealisation because the framework relies on psychological foundations for understanding CSR, specifically those related to IOP (Aguinis \& Glavas, 2013). Embedded CSR is explained by Aguinis and Glavas (2013) as being integrated with an organisation's policy, values, mission and core strategy. Peripheral CSR, on the contrary, is found where an organisation's CSR activities are not integrated with core operations, but rather expressed externally in forms of philanthropy or volunteering.

In South Africa, there is a unique approach to CSR where the principles are accepted positively and as responsible business undertakings. Seen from a South African perspective, responsible business is entrenched as a responsibility and an aspiration for organisations to show that they operate on triple bottom-line perspectives and have excellent corporate citizenship (Ackers, 2015). Furthermore, Ackers (2015) indicates that, in South Africa, a paradigm shift is occurring, businesses are moving towards a system where they want to cooperate and disclose on their social activities, as part of their business operations and not only for those for whom it is promulgated as law. Bringing together the global and the South African contexts is significant for understanding how CSR can be similar and be differentiated. Sivaraman (2013) provides an integrated view of CSR by stating that companies are paying more attention to their responsibilities with regard to society, environments, welfare of workers, resources and charitable contributions. All of these core elements, when they are properly accounted for, can be considered to be socially desirable. This social desirability is the coveted outcomes of CSR, regardless of the context of the CSR initiative (Carroll \& Shabana, 2010; Sivaraman, 2013).

The concept of CSR expands the scope of, and calls the attention of, organisations to take responsibility (Sivaraman, 2013). It is also commented that the rapid economic growth and the impact of climate change contribute to the way CSR has been favourably adopted in South Africa (Sivaraman, 2013). For purposes of this study, CSR is defined and viewed as activities that organisations engage in, forming part of their business operations, which expand favourable outcomes into the communities in which they operate.

\section{Industrial psychology and corporate social responsibility}

Rupp, Skarlicki and Shao (2013) point out that little research has been undertaken to understand CSR from the perspective of IOP, including psychology in general, and how these professionals operate and function to support the social 
duties and responsibilities of modern organisations. Industrial-organisational psychology is a field of psychology that concerns itself with applying psychological theory, practice and principles to the working environment (Schreuder \& Coetzee, 2011). The Health Professions Council of South Africa (HPCSA) is the government's legal entity that governs the practice and scope of, along with regulatory control over, the profession in the country, as indicated in the Health Professions Act of 1974 (South Africa Department of Health, 2011). The HPCSA indicates the scope of the profession for IOP as 'planning, developing, and applying paradigms, theories, models, constructs, and principles of psychology in the workplace in order to understand, modify, and enhance individual, group, and organisational behaviour effectively' (South Africa Department of Health, 2011, p. 9). Definitions of industrial psychology also indicate that the functions of the IOP practitioner include actions outside the industrial setting, such as serving communities and people (Colman, 2015). A core responsibility that needs to be highlighted is designing, managing, conducting, reporting on and supervising industrial psychology research (Health Professions Act, 1974). This would indicate that if an organisation is seeking to engage in CSR, the IOP practitioner will have the eligibility and competencies to act in that capacity, as the IOP has a stake in the research and practice. To further this on the assentation by Ackers (2015), the IOP would be an assent to ensure compliance on a regulatory and voluntary basis. Interestingly, the South African scope of practice for the profession of IOP does not specifically demarcate any official responsibility for the IOP to engage in community engagement or social responsibility, an evident gap in industrial psychology literature.

The evolution, development and progression of IOP as a profession require continuous research and dedication in various areas of interest. Especially of value for this article is the link between CSR and IOP to mental health in communities. The South African National Mental Health Policy Framework and Strategic Plan (2013-2020) states that mental health is an important aspect of health and crucial to the overall well-being of individuals and society. According to Satcher (2000), mental health is more than merely addressing psychiatric disorders. Satcher (2000) states that it is:

$[T]$ he successful performance of mental function, resulting in productive activities, fulfilling relationships with other people, and the ability to adapt to change and to cope with adversity; from early childhood until later life, mental health is the springboard of thinking and communication skills, learning, emotional growth, resilience, and self-esteem. (p. 6)

The definition utilised by Satcher is of importance for the profession of industrial psychology, which often focuses on interventions to develop and grow individuals (South Africa Department of Health, 2011, p. 9).

\section{Goal and contribution of the study}

The general aim of this study was to explore the contribution that the profession of industrial psychology can make towards improving mental health by means of a CSR programme.
The aim of the study leads to the following research questions:

- What does a needs assessment for development and growth indicate from specific role-players in a CSR programme for young adults in a community?

- What is the content and methodology of an IOP-related CSR programme for a specific population of young adults in a community?

By conducting this study, a contribution is made whereby the research indicates that the industrial and organisational psychologists could make a valuable contribution towards CSR initiatives. On individual level, the study contributed to clarify the understanding of where IOP has a place in social investment and contributions. Through the study, a CSR programme for young adults was developed, which suits the context of the profession of industrial psychology.

\section{Research design \\ Research approach and strategy}

This study followed the qualitative research and constructivism approach. In the social constructivism ontology, as described by Kim (2001), multiple realities exist because multiple people have constructed the realities and have lived the experience(s). Social constructivism operates on central assumptions concerning reality, knowledge and learning. In social constructivism, the epistemology in the paradigm notes that the knowledge extracted is subjective to, and constructed from, the social world of the participant. It is explained that this knowledge is bound by culture, context and the world of the person being questioned (Kim, 2001). For the purposes of the study, the authors maintained that social constructivism holds that experiences can only be understood when they are explored from the viewpoint of the person who has lived the experience (Chilisa \& Kawulich, 2012).

This study utilised a case study as the research strategy. When using a case study, a specific population is demarcated and scientifically investigated to generate knowledge, from either a specific individual or a group (Leedy \& Ormond, 2013). For the purposes of this study, a descriptive case study and an instrumental case study were utilised as research strategy. A descriptive case study was used to gather and analyse the data that relate to the phenomenon identified in the research questions (Yin, 2003 cited in Fouché \& Schurink, 2011). Semi-structured interviews were used to execute the case study strategy. This case study required the researcher to be personally involved and entrenched in the particular targeted population of study, in this case IOP students acting as facilitators, and the members involved in the project (e.g. project leader). Some features of the instrumental case study were utilised in producing new knowledge regarding a specific social issue or phenomenon, along with policy development. This study aimed at not only furthering knowledge but also extending the knowledge and theory (e.g. developing a CSR programme) for which the instrumental case study was used (Thomas, 2004). 


\section{Research setting, entrée and researcher roles}

Entrée to the selected participants was gained by the authors by joining an existing CSR project at the IOP department where one of the authors was a postgraduate student. A local community secondary school approached the tertiary institution during the previous year, requesting assistance with regard to a voluntary academic association, which was formed at the school. The institution obliged as part of its CSR initiatives and the institution closed an agreement with the school, resulting in the CSR project. The data were collected at the premises of the tertiary institution in two phases. In the first phase, the participants included the project leader, coordinator and facilitators (namely the IOP students) of the CSR initiative. During the second phase (not reported in this article), the learners from the school shared their experiences after attending the CSR programme. Therefore, for the first phase, the six participants were all invited for the interviews and the purpose of the research was explained to them.

\section{Sample}

Purposive and key informant sampling methods were used in this study. Purposive sampling, also referred to as selective sampling, is suitable when the researcher chooses participants who fit within the parameters of the research objectives, questions and aims (Tracy, 2013). Key informant sampling was applied to access the six participants who possessed specific knowledge for the study (Tongco, 2007). The selection criteria utilised included only members who participated in the specific CSR project as presenters, developers and facilitators, either members of the community, academic staff members or students. The population comprised a group consisting of the project leader $(n=1)$, coordinator $(n=1)$ and facilitators (IOP students) $(n=4)$ of the CSR programme; their biographical information is presented in Table 1.

\section{Data collection}

This study used semi-structured individual interviewing as the method of data collection. The interviews lasted for an average of $45 \mathrm{~min}$ each. Opdenakker (2006) highlights the advantage of interviewing where the possibility to probe and act on social cues creates dynamic and rich data. Care was taken because a disadvantage of interviewing can be that the participants can be influenced by the researcher's behaviour, language, actions or words (Opdenakker, 2006). During the

\begin{tabular}{|c|c|c|}
\hline Position & Population group & Role \\
\hline $\begin{array}{l}\text { Voluntary member of } \\
\text { community }\end{array}$ & White female & Project leader \\
\hline Academic staff member & White male & $\begin{array}{l}\text { Coordinator of CSR programme } \\
\text { at the IOP department }\end{array}$ \\
\hline IOP master's student & White male & Facilitator and researcher \\
\hline IOP master's student & Mixed race male & Facilitator \\
\hline IOP master's student & White male & Facilitator \\
\hline IOP honours student & White male & Facilitator \\
\hline
\end{tabular}

CSR, Corporate Social Responsibility; IOP, Industrial-Organisational Psychology. interview process, the interviewer probed unclear responses to clarify what had been heard, and conversely clarify what had been asked.

\section{Data analysis and interpretation}

Thematic analysis was used to identify the themes or patterns in the data. This technique is used when the researcher attempts to understand the specific phenomenon from the participant's view by looking at how the data from the various participants fit together (Kawulich \& Holland, 2012). The three steps in data analysis, suggested by Kawulich and Holland (2012), were applied. Firstly, the researchers explored the data and developed codes and created sub-categories that applied to the data. Then the codes were grouped together to form categories in an attempt to describe the context or interaction occurring between the codes. In this step, the researchers took apart the data and rearranged it in various ways to identify a way in which the data made sense around categories. In the last step, the codes, themes and categories were detailed to make sense as a whole and it enabled the researchers to create a storyline of the data segment. While interpreting the data, the researchers were aware, as stated by Chilisa and Kawulich (2012), that the social constructivism lens shows the experiences explored from the viewpoint of the participants; however, the researchers were cognisant of the fact that their own interpretations were also based on their own lived experience.

\section{Strategies employed to ensure data quality and integrity}

Qualitative data need to be scientifically accurate and of high quality, and therefore the scrutiny of qualitative data is very important. The indicators of qualitative trustworthiness, according to Kawulich and Holland (2012), were followed, namely, credibility was ensured by applying techniques such as co-coding and triangulation. Transferability was ensured by keeping all data in its original form and by describing the case richly. Dependability for this study was ensured where the design was scientifically planned, executed and continually monitored. The study was documented carefully and reviewed to increase the scientific accuracy of the research. Confirmability for the study aimed at focusing on scientific objectivity; the researchers and authors of the study took great care in remaining impartial and fair; they were unbiased and treated all participants in the same objective manner. Strategies to uphold the integrity of the research were reached by focusing on Kitchener's (1984) five moral principles. Firstly, autonomy, by allowing the participants the freedom of choice and action to share their experiences in the study; secondly, justice, by ensuring that all participants were treated as equal; thirdly, beneficence was ensured by focusing on the well-being of the participants at all times; fourthly, non-maleficence by avoiding causing harm to the participants; and, lastly, fidelity, by being trustworthy throughout the study. 


\section{Findings}

The study's research findings were delineated into a collection of categories, themes, sub-themes and direct quotations acting as corroborative support for the results. Each of the categories with the accompanying themes and sub-themes extracted is presented and detailed below. All of the data collected from the participants in the interviews were in English and therefore no translation was necessary.

To obtain an overview of the findings that follow, the categories with the themes are summarised in Figure 1.

\section{Category 1 - Needs assessment}

The first category identified from the data revolved around the needs assessment of the participants. The themes extracted from the data were obtained from the interviews with the project leader and coordinator of the CSR programme. They were asked how the specific needs of the target population group (learners) were identified, how these needs were managed or categorised and, finally, how they made sense of the needs in terms of the development of the CSR programme. The extracted data could be segmented into five themes with various sub-themes identified. The data are organised in Table 2.

From the data collected, it became obvious that the CSR initiative was preceded by a needs assessment process.

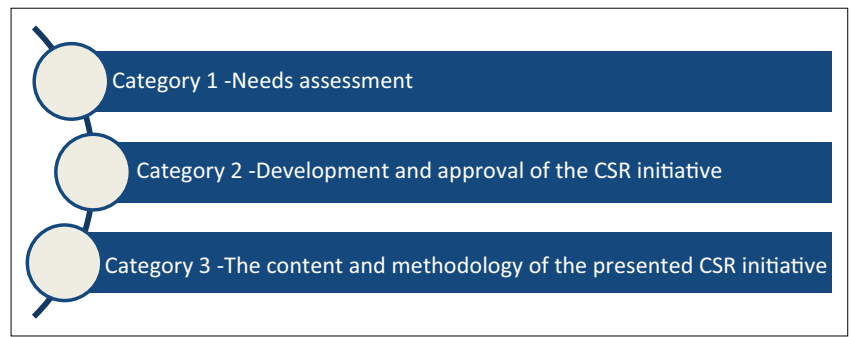

FIGURE 1: Overview of categories.
Although this process commenced spontaneously (from the school requesting assistance), a process followed where sense needed to be made of the requests and to be structured into some kind of programme. A discussion of the sub-themes provides the following regarding the needs identification process.

\section{The school}

From Table 2, it is clear that the community high school was the starting point of the entire programme; it seems that the school struggled with specific learners' behaviour and requested assistance from the project leader. The community high school identified a specific group of learners who were branded for misbehaviours, poor academic progress and general disruptive behaviour. The project leader then referred this group to the coordinator of the programme, where the next phases of needs identification commenced.

\section{The coordinator}

From Table 2, a sub-theme emerged where the needs assessment included a second group, the project leader of the CSR initiative, who approached the institution and coordinator, after the general population had been identified. The coordinator appointed facilitators to the initiative by requesting voluntary assistance from the postgraduate students in the IOP programme. The project leader accepted the broad themes (needs) as proposed by the community school and translated these into general life skills training, such as communication skills, HIV education, sensible relationships, safe sex practices, and dreams and plans for the future. Once the coordinator became involved in the project, the needs identification process delineated more specific needs and topics that needed to be addressed, which also assisted in tailoring the CSR initiative to have specific goals.

\section{Facilitators}

The coordinator held a meeting with colleagues at the tertiary institution and initiated the CSR project. At the meeting,

TABLE 2: Needs assessment.

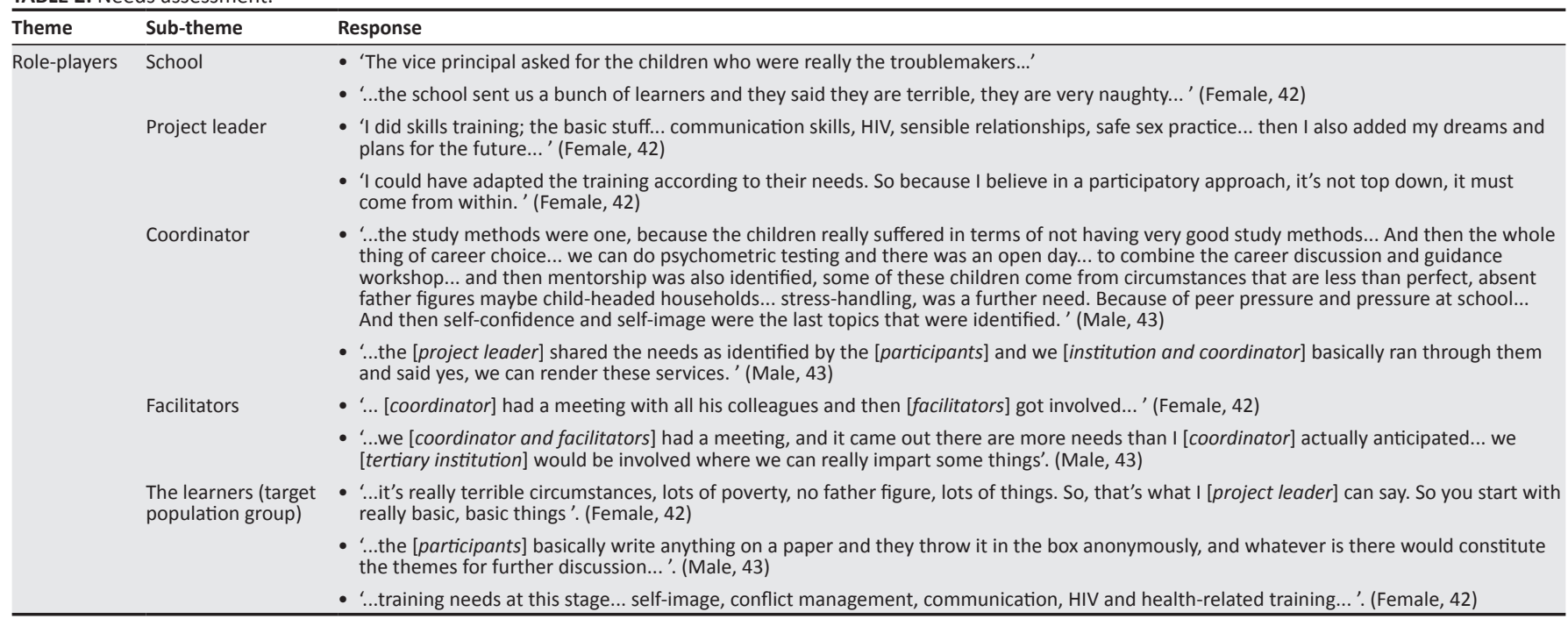


it was realised that the institution can, indeed, impart knowledge and skills related to the identified needs of the participants.

\section{The learners}

The next sub-theme identified from the data included the learners, who communicated their needs anonymously to the project leader. These included needs such as self-image, conflict management, communication, HIV and health-related training. These lists of needs were used as a point of discussion by the coordinator and facilitators to develop a specific plan of action to be incorporated with the CSR initiative.

\section{Category 2 - Development and approval of the corporate social responsibility initiative}

The second category identified from the data has its focus on the development and approval process of the CSR initiative. The central themes of this category covered the development of the programmes, including elements such as the approval process, how the role-players gained access and involvement of different role-players. This data captured from the project leader, coordinator and facilitators provided insight into the technical details of the initiative and also the various aspects contributing to the final product (being the designated workshops). Table 3 provides the themes and sub-themes for the extracted data, segmented into three themes, supported by various sub-themes.

Exploration of the data revealed that the development of the initiative covers how the entire project was conceptualised and how the project leader, coordinator, facilitators and the tertiary institution gained access to, and involvement in, the CSR initiative. The sub-themes relating to the development and approval of the initiative follow; the project leader was the main point of contact for the commencement of the CSR programme. At the time when the project leader was contacted by the school, she was already involved in community outreach programmes. The project leader contacted the coordinator and asked to volunteer assistance because it is expected of the tertiary institution to give back to the community, the coordinator initiated their involvement. The coordinator also realised that the students of the tertiary institution can also be involved. The IOP honours, master's and intern students of the tertiary institution were provided with the opportunity to volunteer their time, knowledge, experience and participation in the initiative.

The second theme in the study revealed the approval process for the CSR programme. The initiative had started as an independent project that was created and established before the participation and involvement of the tertiary institution. The tertiary institution became a role-player when the coordinator realised the potential for the project to be an official CSR initiative. The motivation to bring such a project to the attention of a tertiary institution is that it can expand and grow the initiative by reaching more individuals who can offer assistance and also expand the operational scope of the project. The project was consequently recognised by the tertiary institution and after institutional approval became an official part of the institution's CSR initiatives. The same is true for the facilitators of the project - approval was granted by the tertiary institution before they were approached or designated any duties or roles.

\section{Category 3 - The content and methodology of the presented corporate social responsibility initiative}

In categories 1 and 2, the needs identified specifically from the project leader and coordinators were explained. The next category reports on the findings obtained from the interviews with the project leader, coordinator and facilitators of the CSR programme. The category shows how the needs identified in categories 1 and 2 were translated into a CSR initiative by relating the needs to specific topics. The specific topics that were addressed in the CSR initiative are presented in Table 4.

\section{Ethical considerations}

This study formed part of a research project for which the institution's research board provided ethical clearance and approval, and an ethical clearance number was registered (NWU 00084-10-S4).

TABLE 3: Development and approval of the corporate social responsibility initiative.

\begin{tabular}{|c|c|c|}
\hline Theme & Sub-theme & Response \\
\hline \multirow[t]{4}{*}{$\begin{array}{l}\text { The } \\
\text { development } \\
\text { process }\end{array}$} & The project leader & $\begin{array}{l}\text { - '...She [project leader] had kind of a need to give back to the community... So this group of children came, and I [project leader] just fell } \\
\text { in love with them '. (Male, 43) } \\
\text { - 'I was a project manager at Child-line North-west... in } 2010 \text { the [community high school] sent us a bunch of learners... '. (Female, 42) }\end{array}$ \\
\hline & The coordinator & $\begin{array}{l}\text { - '...but we were able to give each and every [participant] a computer. But it was very heavy for me, so I asked [coordinator] to help me... } \\
\text { I think something in his heart stirred... all of a sudden [coordinator] he said he's going to get involved'. (Female, } 42 \text { ) } \\
\text { - '...It is expected of the [tertiary institution] to be involved in community-related work and [coordinator] came with the idea to involve our } \\
\text { students in issues which are really within the scope...'. (Male, } 43 \text { ) }\end{array}$ \\
\hline & The facilitators & - '...the idea to involve our honours students in one or two issues which are really within the scope '. (Male, 43) \\
\hline & & $\begin{array}{l}\text { - '...we had planning meetings with the honours students and master's students and interns... circulated a name-list for people who would } \\
\text { like to volunteer for this. It is a voluntary thing. With the added benefit that Industrial Psychology students could do some of their practical } \\
\text { hours which is mandatory...' (Male, 43) }\end{array}$ \\
\hline \multirow[t]{3}{*}{$\begin{array}{l}\text { The approval } \\
\text { process }\end{array}$} & $\begin{array}{l}\text { The community } \\
\text { school }\end{array}$ & $\begin{array}{l}\text { - 'There is a letter where they [community school] approve the project as a whole; it does not mention the [tertiary institution]... a general } \\
\text { approval letter...'. (Male, 43) } \\
\text { - '...approval letter that states it can be held with [the participants] and on their premises'. (Male, 43) }\end{array}$ \\
\hline & $\begin{array}{l}\text { The institutional } \\
\text { approval }\end{array}$ & - '...he [institutional director] was very positive, and who also volunteered finances... '. (Male, 43) \\
\hline & & - '...the [tertiary institution] registered the initiative as a community engagement project...'. (Male, 43) \\
\hline
\end{tabular}


TABLE 4: Corporate social responsibility initiative workshop schedule.

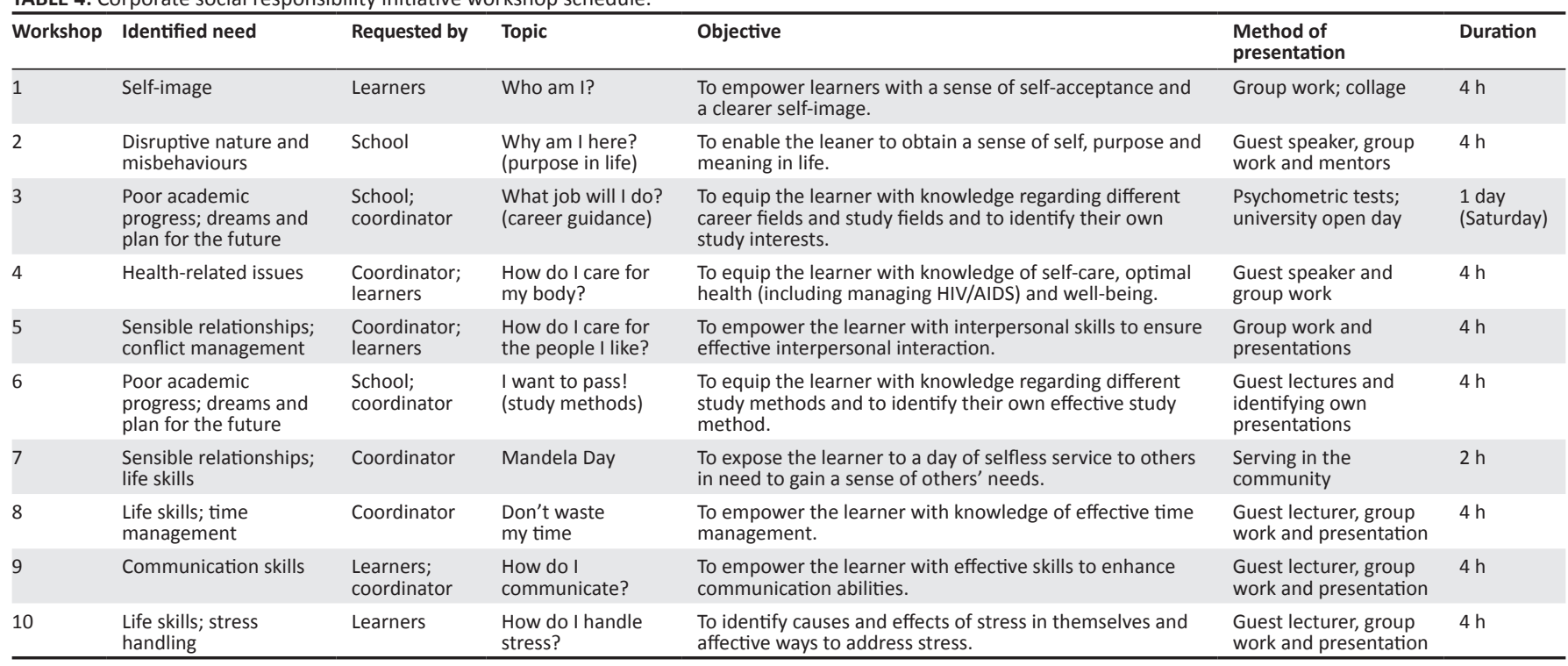

\section{Discussion}

In South Africa, the legal scope of profession does not specifically delineate the responsibility of the industrial psychologist to engage in CSR activities. However, it is written that the functions of the IOP practitioner include actions outside the industrial setting, such as serving communities and people (Colman, 2015). The noteworthy ideology to consider is that the IOP practitioner will have the duty to further the interests of the organisations, and the IOP is equipped to advance the social and ethical endeavours of the organisation, which may typically include CSR activities (Barnard \& Fourie, 2007; Van Vuuren, 2010). In the profession of IOP, a multitude of association bodies also exist that undertake to promote the values of social investment, to which the IOP practitioner can subscribe and, in doing so, advance their CSR interests.

The results from this study showed that the needs analysis process was initiated by the community high school. The school management identified the learners' first needs for specific development and consequently approached the project leader of the CSR initiative for assistance. These identified needs from the school were broad and not directed at specific topics, such as learners who needed guidance, development and general life skills training. The project leader approached the tertiary institution with the needs of the learners and this led to a CSR project being registered at the tertiary institution, and a coordinator was assigned to the initiative. This process of generating a programme for the learners, which addressed their needs, utilised the assistance of the programme's coordinator and the various facilitators (postgraduate IOP students) involved. The research questions of this article were, firstly, to report on the needs assessment for the CSR programme and, secondly, what the content and methodology of an IOP-related CSR programme were to address the needs of the specific population of young adults in the community.
The literature shows that the needs assessment process within CSR can be dynamic and creative. Moir (2001) states that the needs assessment process is primarily driven by what the organisation identifies as a need within the community's reach. Within this process, it is important to understand the needs of all stakeholders involved, and how this inter-relationship will be formed during the process, seeing that the CSR design must reflect the needs of the society (Moir, 2001). Similarly, in the current study, various stakeholders were involved, apart from the learners. Firstly, the local school reached out to the project leader, whereafter the project leader linked up with the tertiary institution's IOP department where a coordinator initiated the programme and involved the IOP postgraduate students. Wang and Burris (1997) also explain the advantages of linking needs assessment with community participation. When the community involved participates in the process of needs identification, the effectiveness and applicability of the initiative are increased. It also assists the project designers in gaining perspective from the views and lives of the participants (Wang \& Burris, 1997) - as was the case in this study.

The needs assessment process flowed into a CSR initiative with a tertiary institution. The data revealed two categories: the development process of the CSR initiative and the approval process followed to realise the initiative. An interesting finding is that the learners themselves had a role to play in the development of the content of the initiative. These learners had taken the enterprise to establish a youth group, taking responsibility for their own internal structure complete with their own vision, mission and portfolios. The project leader also has a keen interest and experience in community-related work and utilised that skill set to be integrated with the initiative. The results revealed that the coordinator and facilitators gained access to the participant group because of their interest in IOP - the same fact being true for the tertiary institution and the related role-players in the current study. Humphrey (2013) indicates that communities are 
often unaware of the beneficial contributions that tertiary institutions can have in communities, especially excluded or disadvantaged communities. The benefits of the tertiary institutions include offerings such as service learning, continuous professional development offering, education, widening access and volunteering, which are all facets that are available to use in community engagement initiatives (Humphrey, 2013). Tertiary institutions are increasingly involved as active role-players in community engagement (Olowu, 2012). Vickers and McCarthy (2004) opine that universities are in a prime position to impart relevant knowledge into communities, especially considering they primarily are institutions of teaching and education. Furthermore, universities are able to engage with communities to provide service learning, which enables students to also play a part with community engagement, and an interrelationship of benefits is established for the community, students and universities (Vickers \& McCarthy, 2004).

As found by Shiel, Leal Filho, Do Paço and Brandli (2016), this study's contributors to the initiative had done so completely voluntarily. The students who acted as facilitators had the added benefit of service training and learning added to their voluntary participation. The process followed garnered support and approval from the participants and the tertiary institution. To develop the content for the CSR programme, the needs assessment was utilised, which revealed specific themes for this specific group. The themes included, firstly, self-image relating to the learners' sense of self-acceptance and a clearer self-image. According to Switzer, Simmons, Dew, Regalski and Wang (1995), the topic relating to self-image development is often found in CSR initiatives among learners when addressing life skills. Switzer et al. (1995) found that school-based programmes that focused on self-image led to participants experiencing positive growth in self-esteem, commitment to school and community, and improvement in problematic behaviour. The second topic dealt with purpose in life, namely, to enable the learner to obtain a sense of self, purpose and meaning in life. Pittman, Irby, Tolman, Yohalem and Ferber (2003) state that moral, spiritual and individual sense of self and purpose in life is an area of development recognised for all adolescents and young adults, as these skills are essential for goal attainment and needs fulfilment. The next topic identified by the participants in the CSR programme related to addressing health-related issues such as HIV and AIDS, basic wellness and health, and taking care of one's body, which is considered to be of integral importance in such development programmes. Addressing health-related issues among young adults is a major concern globally (Jackson et al., 2007). Roth, Brooks-Gunn, Murray and Foster (1998) also indicate that community youth development programmes incorporating health-related issues training show better positive outcomes for participants. Other topics included in the programme in the study related to effective interpersonal communication, enabling the participants to increase their communication skills. Eccles and Gootman (2002) suggest that conflict and relationship management training is an effective tool for decreasing aggressive behaviour and conflict incidences.

In addition, effective communication training also produces increased warmth, connectedness and supportive relationships (Eccles \& Gootman, 2002). The topic list also addressed career guidance and study methods in the CSR initiative. The third topic of career guidance is similarly linked to the ideals of Pittman et al. (2003), where it is said that young adults seek career guidance reportedly because they need to know what to study to make a difference in their career paths. Concerning study methods, Ramdass and Zimmerman (2008) found that training students in various methods of studying or learning increases student self-efficacy, self-regulation, motivation and confidence. The participants further stated that they would like to include the topic of dealing with stress, relating to identification, and management of stress. Eccles and Gootman (2002) opined that these types of interventions result in reduced report of stress-related symptoms and increased ability to recognise stress symptoms. The topics focusing on time management are also indicated to be of value to the participants. Time management skills training has been shown to be positively related with self-regulation and control of time resources and negatively related with stress (Claessens, Van Eerde, Rutte, \& Roe, 2007). Last but not least, the participants indicated that they would like to give back to the community in an unselfish manner. For this purpose, they decided to take part in the South African initiative Mandela Day (which they referred to as Madiba Day) (Mandeladay, 2016).

The results from this study echo the report by Satcher (2000), stating that mental health can be viewed as having fulfilling relationships with other people; also, mental health is the springboard of thinking and communication skills, learning, emotional growth, resilience and self-esteem. Moreover, it is evident from the study that the learners voiced their need to obtain the skills that can be viewed as attributes of mental health. Brainscape (2019) reported that attributes of mental health can be viewed as the ability to love, deal with conflicting emotions, control one's own behaviour, relate to others, manage interpersonal conflict, ability to work and be productive, have a healthy self-concept and self-value, to name but a few. These attributes were all identified as needs by the participants in the study and translated into a CSR initiative ideally suited within the IOP context.

Referring to the methodology employed to present the CSR initiative, different approaches were followed to present the content of the programme, such as group discussions, role-plays, mentors, guest lecturers and practical activities. The project leader of the initiative indicated that the philosophy of the initiative was to be driven from the bottomup and not merely by a lecture to the participants, but rather a collaborative training effort. The application of different learning techniques was employed to cater for different learning styles. Therefore, experiential learning was mainly used because the learning process is perceived to be involved and inclusionary of individual needs (Peterson, DeCato, \& 
Kolb, 2015). The initiative followed a specific schedule that contained the different topics for the workshops. This schedule was used to guide the role-players of the initiative to address all the identified needs, in accordance with the planned philosophy and approach towards learning.

\section{Conclusion}

This study primarily endeavoured to contribute to the field of research in IOP by exploring the knowledge regarding social contributions and community engagement, especially to address mental health in a specific community. The results indicate that CSR, IOP and mental health have a complementary relationship. Conclusively, the study shows that industrial and organisational psychologists have the skills to operationalise CSR triumphantly. The findings also showed that the attributes of mental health can easily be facilitated within a CSR programme that fits in the scope of practice of the industrial psychologist. Recommendations for future research would be to conduct similar investigations at other tertiary institutions that also offer IOP-related CSR initiatives to monitor the impact of CSR initiatives when executed from psychology or related departments.

\section{Acknowledgements}

The authors would like to acknowledge and express their appreciation to all the participants who took part in the project and study.

\section{Competing interests}

The authors declare that they have no financial or personal relationships that may have inappropriately influenced them in writing this article.

\section{Authors' contributions}

D.V. collected the interview data and was the main author of the article. L.I.J.-G. was the research initiator and research project leader, collected the interview data and prepared the article for publication. B.E.J. was the coordinator of the corporate social responsibility initiative.

\section{Funding information}

This research received no specific grant from any funding agency in the public, commercial or not-for-profit sectors.

\section{Data availability statement}

Data sharing is not applicable to this article as no new data were created or analysed in this study.

\section{Disclaimer}

The views and opinions expressed in this article are those of the authors and do not necessarily reflect the official policy or position of any affiliated agency of the authors.

\section{References}

Ackers, B. (2015). Ethical considerations of corporate social responsibility - A South African perspective. South African Journal of Business Management. Retrieved from http://reference.sabinet.co.za/webx/access/electronic journals/busman/ busman_v46_n1_a2.pdf.

Aguinis, H., \& Glavas, A. (2012). What we know and don't know about corporate social responsibility: A review and research agenda. Journal of Management, 38(4), 932-968. https://doi.org/10.1177/0149206311436079

Aguinis, H., \& Glavas, A. (2013). Embedded versus peripheral corporate social responsibility: Psychological foundations. Industrial and Organizational Psychology: Perspectives on Science and Practice, 6, 314-332

Barnard, G., \& Fourie, L. (2007). Exploring the roles and contributions of industrial psychologists in South Africa against a multi-dimensional conceptual framework (part 2). SA Journal of Industrial Psychology, 33(2), 45-53. https://doi.org/10.4102/ sajip.v33i2.376

Carroll, A.B., \& Shabana, K.M. (2010). The business case for corporate social responsibility: A review of concepts, research and practice. International Journal of Management Reviews, 12(1), 85-105. https://doi.org/10.1111/j.1468-2370. 2009.00275.x

Chilisa, B., \& Kawulich, B.B. (2012). Selecting a research approach: Paradigms, methodology and methods. In C. Wagner, B.B. Kawulich, \& M. Garner (Eds.), Doing social research: A global context (pp. 52-61). New York: McGraw-Hill Higher Education.

Claessens, B.C., van Eerde, W., Rutte, C.G., \& Roe, R.A. (2007). A review of the time management. Personnel Review, 36 (2), 255-276.

Colman, A.M. (2015). A dictionary of psychology (4th edn.). Oxford: Oxford University Press.

Dahlsrud, A. (2008). How corporate social responsibility is defined: An analysis of 37 definitions. Corporate Social Responsibility and Environmental Management, 15(1), 1.

Eccles, J., \& Gootman, J.A. (2002). Community programmes to promote youth development. Washington, DC: National Academy Press.

Fouché, C.B., \& Schurink, W. (2011). Qualitative research designs. In A.S. De Vos, H. Strydom, C.B. Fouché, \& C.L.S. Delport (Eds.), Research at grass roots: For the social sciences and human services professions (4th edn., pp. 307-327). Pretoria: Van Schaik.

Gilbert, D.U., Rasche, A., Schormair, M.J.L., \& Singer, A. (2019). Special Issue on: The challenges and prospects of deliberative democracy for corporate sustainability and responsibility. Business Ethics Quarterly, 29(2), 285-289. https://doi.org/ 10.1017/beq.2019.2

Humphrey, L. (2013). University-community engagement: Dislocation of theory and practice. In P. Benneworth (Ed.), University engagement with socially excluded communities (pp. 103-124). Dordrecht, Heidelberg, London, New York: Springer.

Jackson, S.F., Perkins, F., Khandor, E., Cordwell, L., Hamann, S., \& Buasai, S. (2007). Integrated health promotion strategies: A contribution to tackling current and future health challenges. Health Promotion International, 21(1), 75-83. http:// doi.org/10.1093/heapro/dal054

Kawulich, B.B., \& Holland, L. (2012). Qualitative data analysis. In C. Wagner, B.B. Kawulich, \& M. Garner (Eds.), Doing social research: A global context (pp. 228-245). New York: McGraw-Hill Higher Education.

Kim, B. (2001). Social constructivism. Emerging Perspectives on Learning, Teaching, and Technology, 1(1), 16

Kitchener, K.S. (1984). Intuition, critical evaluation and ethical principles: The foundation for ethical decisions in counseling psychology. Counseling Psychologist, 12(3), 43-55. https://doi.org/10.1177/0011000084123005

Leedy, P.D., \& Ormrod, J.E. (2013). Qualitative research. In P.D. Leedy \& J.E. Ormrod (Eds.), Practical research: Planning and design (10th edn., pp. 139-169). Upper Saddle River, NJ: Pearson Education.

Mandela day. (2016). What is Mandela day? - Mandela day. Retrieved from http:// www.mandeladay.com/content/landing/What-is-Mandela-Day.

Moir, L. (2001). What do we mean by corporate social responsibility? Corporate governance: The International Journal of Business in Society, 1(2), 16-22. http:// doi.org/10.1108/EUM0000000005486

Moura-Leite, R.C., \& Padgett, R.C. (2011). Historical background of corporate social responsibility. Social Responsibility Journal, 7(4), 528-539. https://doi.org/ 10.1108/1747111111117511

Okpara, J.O., \& Idowu, S.O. (2013). Corporate social responsibility, J.O. Okpara \& S.O. Idowu (Eds.). Berlin, Heidelberg: Springer. https://doi.org/10.1007/978-3-642-40975-2

Olowu, D. (2012). University-community engagement in South Africa: Dilemmas in benchmarking. South African Review of Sociology, 43(2), 89-103. https://doi.org/ 10.1080/21528586.2012.694252

Opdenakker, R. (2006). Advantages and disadvantages of four interview techniques in qualitative research 2. Forum: Qualitative Social Research, 7(4), 1-9.

Peterson, K., DeCato, L., \& Kolb, D.A. (2015). Moving and learning: Expanding style and increasing flexibility. Journal of Experiential Education, 38(3), 228-244. http://doi. org/10.1177/1053825914540836

Pittman, K., Irby, M., Tolman, J., Yohalem, N., \& Ferber, T. (2003). Preventing problems, promoting development, encouraging engagement: Competing priorities or inseparable goals? Washington, DC.: The Cady-Lee House.

Ramdass, D., \& Zimmerman, B. (2008). Effects of self-correction strategy training on middle school students' self-efficacy, self-evaluation, and mathematics division learning. Journal of Advanced Academics, 20(1), 18-41. https://doi.org/10.4219/ jaa-2008-869 
Rossouw, D., \& Van Vuuren, L. (2010). Business ethics (4th edn.). Cape Town, South Africa: Oxford University Press.

Roth, J., Brooks-Gunn, J., Murray, L., \& Foster, W. (1998). Promoting healthy adolescents: Synthesis of youth development programmes evaluations. Journal of Research on Adolescence, 8(4), 423-459. https://doi.org/10.1207/s15327 795jra0804_2

Rupp, D.E., Skarlicki, D., \& Shao, R. (2013). The psychology of corporate social responsibility and humanitarian work: A person-centric perspective. Industrial and Organizational Psychology, 6(4), 361-368. https://doi.org/10.1111/iops.12068

Satcher, D. (2000). Mental health: A report of the surgeon general - Executive summary. Professional Psychology: Research and Practice, 31(1), 5-13. https:// doi.org/10.1037/0735-7028.31.1.5

Schreuder, A.M.G., \& Coetzee, M. (2011). Careers: An organisational perspective (4th edn.). Cape Town: Juta.

Serenko, A., \& Bontis, N. (2009). A citation-based ranking of the business ethics scholarly journals. International Journal of Business Governance and Ethics, 4(4), 390. https:// doi.org/10.1504/IJBGE.2009.023790

Shiel, C., Leal Filho, W., do Paço, A., \& Brandli, L. (2016). Evaluating the engagement of universities in capacity building for sustainable development in local communities. Evaluation and Program Planning, 54, 123-134. https://doi.org/10.1016/j. evalprogplan.2015.07.006

Sivaraman, M. (2013). Corporate social responsibility: Readings and cases in a global context. International Journal of Environmental Studies, 70(4), 675-678. https:// doi.org/10.1080/00207233.2013.841036

Smith, C. Mental health and mental illness. Retrieved n.d., from www.brainscape. com/flashcards/chapter-2-mental-health-and-mental-illnes-5990124/packs/ 9111202 Article.
South Africa Department of Health. (2011). Health Professions Act, 1974: Regulations defining the scope of the profession of psychology. (Government Gazette, 34581 Notice 10505, 2 September 2011). Pretoria: Government Printer.

Switzer, G.E., Simmons, R.G., Dew, M.A., Regalski, J.M., \& Wang, C.-H. (1995). The effect of a school-based helper program on adolescent self-image, attitudes, and behavior. The Journal of Early Adolescence, 15(4), 429-455. https://doi.org/ $10.1177 / 0272431695015004003$

Thomas, A.B. (2004). Research skills for management studies. London: Routledge.

Tongco, D.C. (2007). Purposive sampling as a tool for informant selection. Ethnobotany Research and Applications, 5, 147-158. https://doi.org/10.17348/era.5.0. $147-158$

Tracy, S.J. (2013). Interview planning and design - Sampling, recruiting, and questioning. In S.J. Tracy (Ed.), Qualitative research methods: Collecting evidence, crafting analysis, communicating impact (pp. 131-152). Chichester, West Sussex: Wiley-Blackwell.

Van Vuuren, L. (2010). Industrial psychology: Goodness of fit? Fit for goodness? SA Journal of Industrial Psychology, 36(2), 1-16. https://doi.org/10.4102/sajip. v36i2.939

Vickers, M., Harris, C. \& McCarthy, F. (2004). University-community engagement: Exploring service-learning options within the practicum. Asia-Pacific Journal of Exploring service-learning options within the practicum. Asia-Pacific Journal of
Teacher Education, 32(2), 129-141. https://doi.org/10.1080/1359866042000 234223

Wang, C., \& Burris, M.A. (1997). Photovoice: Concept, methodology, and use for participatory needs assessment. Health Education \& Behavior, 24(3), 369-387. https://doi.org/10.1177/109019819702400309

Yin, R.K. (2003). Case study research: Design and methods (3rd edn.). Thousand Oaks, CA: Sage. 